\title{
A case of nonarteritic anterior ischemic optic neuropathy of a male with family history of the disease after receiving sildenafil
}

This article was published in the following Dove Press journal:

Clinical Ophthalmology

6 October 2011

Number of times this article has been viewed

\section{T Felekis'}

I Asproudis'

K Katsanos ${ }^{2}$

EV Tsianos ${ }^{2}$

'University Eye Clinic of Ioannina, Ioannina, Greece; ${ }^{2}$ First Department of Internal Medicine, University Hospital of Ioannina, Ioannina, Greece

Correspondence: loannis Asproudis University Eye Clinic of loannina, Kosti Palama I, Anatoli-loannina 45500, Greece Tel +30 6945385626

Fax +302651043689

Email asproudisi@yahoo.gr
Abstract: A 51-year-old male was referred to the University Eye Clinic of Ioannina with nonarteritic anterior ischemic optic neuropathy (NAION) 12 hours after receiving sildenafil citrate $\left(\right.$ Viagra $\left.^{\circledR}\right)$. Examination for possible risk factors revealed mild hypercholesterolemia. Family history showed that his father had suffered from bilateral NAION. Although a cause-and-effect relationship is difficult to prove, there are reports indicating an association between the use of erectile dysfunction agents and the development of NAION. Physicians might need to investigate the presence of family history of NAION among systemic or vascular predisposing risk factors before prescribing erectile dysfunction drugs.

Keywords: sildenafil, nonarteritic anterior ischemic optic neuropathy, erectile dysfunction drugs, family history

\section{Case report}

A nonsmoker 51 year-old man used sildenafil citrate $\left(\right.$ Viagra $\left.^{\circledR}\right)$ for erectile dysfunction. The patient did not clarify the quantity of the drug that he used the previous day, but he mentioned during history recording that he had been using this specific agent for the last 6 months at least once a week. The patient did not receive any other treatments before this attack.

The following morning, he noted painless blurred vision in his right eye and he was referred to the University Eye Clinic of Ioannina. Ophthalmologic examination revealed a corrected visual acuity of $1 / 10$ for the right eye and 10/10 for the left eye. Examination of the pupils showed a relative afferent pupillary defect of the right pupil. Biomicroscopy of the anterior segment did not show any pathological manifestations. Intraocular pressure was $12 \mathrm{mmHg}$ for both eyes. The color vision score for the affected eye was 10 out of 15 Ishihara plates while the unaffected eye had a score of 15 out of 15 .

Dilated fundus examination revealed swelling of the right optic disk while the vessels, macula, and the peripheral retina were normal. Goldmann perimetry showed superior visual field loss of the right eye. Fluoroangiography revealed hyperfluorescence of the right optic disk and leakage from it, indicating edema. The patient was not hyperopic and the cup-to-disk ratio in the fellow eye was 0.3 .

Laboratory tests excluded diabetes, sarcoidosis, blood dyscrasias, and hypercoagulable states. Syphilis screening tests, antinuclear antibodies, antinuclear cytoplasmic antibodies, and anticardiolipin antibody tests were all negative. In addition, laboratory screening revealed that erythrocyte sedimentation rate, C-reactive protein, and blood 
count were in the normal range. There was, however, mild hypercholesterolemia $(220 \mathrm{mg} / \mathrm{dL})$. Chest radiography was normal. A magnetic resonance image scan of the brain and orbits with gadolinium demonstrated normal optic nerves and no white matter lesions. A Doppler ultrasound of the carotid arteries and neurological examination were also normal.

The above mentioned results led to the conclusion that the patient had experienced a NAION attack on his right eye. He was consulted to discontinue the use of sildenafil citrate. The patient was subjected to three subtenon injections of beta-methoxazone with a 20-day interval in between.

Visual acuity at the last follow-up evaluation, 1 year after the initial attack, improved to $8 / 10$ for the right eye with ensued optic disk atrophy yet without any significant improvement concerning the impaired visual field.

\section{Discussion}

NAION is the most common acute optic neuropathy in older age groups with an estimated annual incidence of 2.3 per $100,000 .^{1,2}$ It is presumed to result from circulatory insufficiency within the optic nerve head, but the specific mechanism of the vasculopathy remains unproven. Therefore, the most important considerations in understanding the development of NAION are the factors that influence blood flow in the optic nerve head.

Hypovolemia, mainly due to severe surgical procedures, ${ }^{3,4}$ atherosclerotic risk factors, ${ }^{5}$ hypercoagulable states, ${ }^{6-8}$ and crowded optic disk, ${ }^{9}$ in possible combination with regional vascular endothelial disorders has been implicated in the pathophysiology of NAION.

Over the last few years there has been an increasing number of case reports concerning patients who have developed NAION soon after the use of sildenafil and other phosphodiesterase type 5 inhibitors. ${ }^{10-13}$ It has been hypothesized that these agents might exaggerate the physiologic nocturnal hypotension resulting in ischemia to the optic nerve head or that they might interfere with the autoregulation of blood flow thereby decreasing perfusion to the optic nerve head. ${ }^{14}$ In most of the reported cases of NAION after the use of sildenafil, patients detected visual loss upon awakening in the morning. It is usually described 6-36 hours after use of the agent, as it was in this case.

The majority of affected users of phosphodiesterase type 5 inhibitors suffer already from other possible risk factors for NAION. In a retrospective matched case-control study, 38 patients with NAION and age-matched controls without previous history of NAION were questioned for the use of erectile dysfunction agents. The study showed that men with a history of myocardial infarction or hypertension are at increased risk for NAION when using sildenafil or taldenafil. $^{15}$

In this case, the patient had mild hypercholesterolemia without any other systemic or vascular predisposing risk factors based on clinical examination and the rest of the screening as described above. However, the family history of his father having suffered from bilateral attacks of NAION indicates the possible presence of anatomical or other unidentified risk factors for the development of NAION.

The role of hereditary factors in familial NAION remains unknown and the only clinical difference between classical and familial NAION is that the familial type seems to have an earlier onset and a higher frequency of bilateral disease. ${ }^{16}$

This case might support all previous indications of the association between NAION and the use of erectile dysfunction drugs. Since it seems that sildenafil can provoke NAION in some individuals who have a risk profile, the physician might need to investigate the presence of a family history of NAION among other risk factors before prescribing erectile dysfunction drugs.

\section{Disclosure}

The authors report no conflicts of interest in this work.

\section{References}

1. Salomon O, Huna-Baron R, Kurtz S, et al. Analysis of prothrombotic and vascular risk factors in patients with nonarteritic ischemic optic neuropathy. Ophthalmology. 1999;106(4):739-742.

2. Characteristics of patients with nonarteritic anterior ischemic optic neuropathy eligible for the Ischemic Optic Neuropathy Decompression trial. Arch Ophthalmol. 1996;114(11):1366-1374.

3. Foroozan R, Varon J. Bilateral anterior ischemic optic neuropathy after liposuction. J Neuroophthalmol. 2004;24(3):211-213.

4. Servilla KS, Groggel GC. Anterior ischemic optic neuropathy as a complication of hemodialysis. Am J Kidney Dis. 1986;8(1):61-63.

5. Hayreh SS, Joos MK, Podhajsky AP, Long CR. Systemic diseases associated with nonarteritic anterior ischemic optic neuropathy. Am J Ophthalmol. 1994;118(6):766-780.

6. Nagy V, Steiber Z, Takacs L, et al. Trombophilic screening for nonarteritic anterior ischemic optic neuropathy. Graefes Arch Clin Exp Ophthalmol. 2006;244(1):3-8.

7. Felekis T, Kolaitis NI, Kitsos G, Vartholomatos G, Bourantas KL, Asproudis I. Thrombophilic risk factors in the pathogenesis of nonarteritic anterior ischemic optic neuropathy patients. Graefes Arch Clin Exp Ophthalmol. 2010;248(6):877-884.

8. Acheson JF, Sanders MD. Coagulation abnormalities in ischemic optic neuropathy. Eye (Lond). 1994;8(Pt 1):89-92.

9. Beck RW, Savino PJ, Repka MX, Schatz NJ, Sergott RC. Optic disk structure in anterior ischemic optic neuropathy. Ophthalmology. 1984;91(11):1334-1337.

10. Pomeranz HD, Smith KH, Hart WM Jr, Egan RA. Sildenafil-associated nonarteritic anterior ischemic optic neuropathy. Ophthalmology. 2002;109(3):584-587.

11. Lee AG, Newman NJ. Erectile dysfunction drugs and nonarteritic anterior ischemic optic neuropathy. Am J Ophthalmol. 2005;140(4): 707-708. 
12. Pomeranz HD, Bhavsar AR. Nonarteritic anterior ischemic optic neuropathy developing soon after use of sildenafil (viagra): a report of seven new cases. J Neuroophthalmol. 2005;25(1):9-13.

13. Cunningham AV, Smith KH. Anterior ischemic optic neuropathy associated with viagra. J Neuroophthalmol. 2001;21(1):22-25.

14. Danesh-Meyer HV, Levin LA. Erectile dysfunction drugs and risk of anterior ischaemic optic neuropathy: casual or causal association? Br J Ophthalmol. 2007;91(11):1551-1555.
15. McGwin G Jr, Vaphiades MS, Hall TA, Owsley C. Non-arteritic anterior ischaemic optic neuropathy and the treatment of erectile dysfunction. Br J Opthalmol. 2006;90(2):154-157.

16. Hayreh SS, Fingert JH, Stone E, Jacobson DM. Familial non-arteritic anterior ischemic optic neuropathy. Graefes Arch Clin Exp Ophthalmol. 2008;246(9):1295-1305.

\section{Publish your work in this journal}

Clinical Ophthalmology is an international, peer-reviewed journal covering all subspecialties within ophthalmology. Key topics include: Optometry; Visual science; Pharmacology and drug therapy in eye diseases; Basic Sciences; Primary and Secondary eye care; Patien Safety and Quality of Care Improvements. This journal is indexed on

Submit your manuscript here: http://www.dovepress.com/clinical-ophthalmology-journal

\section{Dovepress}

PubMed Central and CAS, and is the official journal of The Society of Clinical Ophthalmology (SCO). The manuscript management system is completely online and includes a very quick and fair peer-review system, which is all easy to use. Visit http://www.dovepress.com/ testimonials.php to read real quotes from published authors. 